\title{
Aprendendo a ensinar com metodologias inovadoras de ensino: um relato de experiência em trabalho interprofissional com docentes de um curso de medicina na Amazônia ocidental
}

\author{
Daniela Moreira Quinto de Sousa Guimarães, Catarina Augusta Vaquer Araújo
}

\begin{abstract}
Resumo
Introdução: Mudanças são necessárias na educação de profissionais da área da saúde para alcançar um trabalho interprofissional de qualidade. A utilização de metodologias inovadoras de ensino ainda na graduação pode modificar as ações dos egressos na prática de saúde nesse sentido. Objetivos: Promover a integração interprofissional entre os docentes do Curso de Medicina, padronizando subsídios de planejamento docente, avaliação e registro das atividades acadêmicas. Fomentar a necessidade de interdisciplinaridade através de estratégias de ensino ativador. Métodos: Foram realizadas oficinas com os docentes do primeiro ano de um Curso de Medicina localizado em um dos Estados que compõe a Amazônia Ocidental. Esses foram organizados em grupos com até cinco participantes, utilizando o Arco de Maguerez para construir conhecimentos sobre as seguintes temáticas: Metodologias Ativas e andragogia, elaboração de questões, avaliação formativa, mapas conceituais e contrato pedagógico. Resultados: Participaram em média 10 docentes: dois médicos, uma médica veterinária, dois enfermeiros, um estatístico, um sociólogo e três biomédicos. Os produtos foram expostos ao grande grupo. Esses se posicionaram como alunos ativos na construção interprofissional de novos conhecimentos e apresentaram produtos de qualidade oriundos das temáticas desenvolvidas. Ao final, verbalizaram satisfação com o trabalho desenvolvido, porém, apresentaram ansiedade pelo novo, natural pelo fato de serem em sua maioria bacharéis ou adeptos das tendências tradicionais de ensino. Conclusões: O trabalho em pequenos grupos com o Arco de Maguerez proporcionou uma interação interprofissional ímpar. Esse, portanto, foi o primeiro dos vários trabalhos desenvolvidos nesse curso com a intenção de melhorar o ensino nesse Curso.

Descritores: Educação Médica, Oficina de Trabalho, Aprendizado Ativo.
\end{abstract}

